\title{
Solubilized Micellar Calcium Induced Low Methoxyl-Pectin Aggregation During Milk Acidification
}

\author{
F. M. Harte, ${ }^{1}$ C. Montes, M. Adams, and M. F. San Martin-Gonzalez \\ Department of Food Science and Technology, The University of Tennessee, 2509 River Dr., Knoxville 37996
}

\begin{abstract}
Low methoxyl (LM) pectin was combined with 3-kDa molecular weight cut-off permeates from milk subjected to $\mathrm{pH} 6.7$ to 5 and $7^{\circ} \mathrm{C}$ or $40^{\circ} \mathrm{C}$ with the objective of studying the effect of solubilized micellar calcium on viscoelastic properties of LM-pectin-milk mixes. Lowering the $\mathrm{pH}$ of skim milk with hydrochloric acid during ultrafiltration gradually promoted permeates to exhibit gel-like behavior when combined with LM-pectin. The onset of the gel-like behavior $\left(\mathrm{G}^{\prime}>1\right)$ occurred at a higher $\mathrm{pH}$ when permeates were obtained from milk filtered at $7^{\circ} \mathrm{C}$ compared with $40^{\circ} \mathrm{C}$. As $\mathrm{pH}$ value during ultrafiltration approached 5 and regardless of temperature, $G^{\prime}$ for permeate-pectin mixes approached the same values $(\sim 70 \mathrm{~Pa})$ as $\mathrm{G}^{\prime}$ for skim milk-pectin mixes. In all cases $\mathrm{G}^{\prime}$ was highly correlated with free calcium concentration $(r>0.95)$. The gradual acidification of skim milk-LM-pectin using glucono- $\delta$-lactone, promoted a sharp increase in storage modulus as $\mathrm{pH}$ approached 5.2 and a maximum $\mathrm{G}^{\prime}$ increment $\left(\Delta \mathrm{G}^{\prime}\right)$ at $\mathrm{pH}$ 4.9. From pH 4.9 to $4, \mathrm{G}^{\prime}$ continued to increase but at smaller increments. It was concluded that LM-pectincasein micelle interaction in milk is a 2-step process: 1) solubilized micellar calcium dependent pectin-pectin interaction as $\mathrm{pH}$ approaches 5.0 to 4.9 , and 2) pectincasein micelle interaction in the $5.0-4.9$ to $4.0 \mathrm{pH}$ range. Key words: casein micelle, pectin, calcium, milk
\end{abstract}

\section{INTRODUCTION}

As $\mathrm{pH}$ drops during fermentation or acidification, steric and electrostatic repulsion of adjacent casein micelles is reduced and micellar aggregation-flocculation occurs (Fox and McSweeney, 1998; de Kruif, 1999). The use of pectin prevents casein micelle aggregation, and it is widely accepted that, at low $\mathrm{pH}(\sim 5)$, pectin is adsorbed to casein micelles, constituting a physical barrier to aggregation (Tuinier et al., 2002). Pectin adsorp-

Received September 27, 2006.

Accepted February 5, 2007.

${ }^{1}$ Corresponding author: fede@utk.edu tion does not occur at $\mathrm{pH}$ of milk ( $\sim 6.6)$, but a depletionflocculation phase separation is promoted provided a minimum pectin concentration is present (Maroziene and de Kruif, 2000). Maroziene and de Kruif (2000) suggested that adsorption of pectin onto casein micelles occurred as $\mathrm{pH}$ drops to 5.3. Later, Tuinier et al. (2002) determined that little adsorption of pectin occurred above $\mathrm{pH} 5.0$ and that electro-sorption was the driving force for the adsorption of pectin as the casein micelle became less negatively charged. Adsorption of pectin into casein micelles occurs only at charged blocks while uncharged groups stretch into the serum, acting as physical barriers to micellar aggregation (Everett and McLeod, 2005). Although this model is widely accepted for low methoxyl (LM) and high methoxyl pectin, little is known on how solubilized micellar calcium (Le Graet and Gaucheron, 1999) affects pectin gelation. Calcium and phosphate transport from mother to offspring is considered the main biological function of the casein micelle in nature (Horne, 2003). Bovine milk is calcium oversaturated ( $\sim 29.4 \mathrm{mM}$; Holt and Jenness, 1984) and although calcium is mostly retained by the casein micelles ( 20.2 mM; Holt and Jenness, 1984), micellar calcium migrates to the serum phase during acidification (Law, 1996) and may promote LM-pectin aggregation (Morris, 1998).

The objective of this study was to determine the effect of $\mathrm{pH}$-induced micellar calcium solubilization on the rheological behavior of LM-pectin during milk acidification.

\section{MATERIALS AND METHODS}

\section{Ultrafiltration Setup}

Skim milk grade A (3 L) was bought in a local grocery store, transferred to an insulated container, and kept under continuous agitation and constant temperature $\left(7\right.$ or $40^{\circ} \mathrm{C}$ ) using a custom-made spiral heat exchanger connected to a controlled temperature water bath. From the container, milk was pumped through $3-\mathrm{kDa}$ molecular weight cut-off (MWCO) tangential flow filter (Prep/ Scale $0.557 \mathrm{~m}^{2}$ of regenerated cellulose, Millipore Corp., Bedford, MA) at $135 \mathrm{kPa}$ constant pressure, with per- 
meate and retentate recirculated to the bulk milk. While filtering, $\mathrm{pH}$ was gradually dropped from 6.7 to 5 using $6 \mathrm{~N} \mathrm{HCl}$ (Fisher Scientific, Fair Lawn, NJ). High $\mathrm{HCl}$ normality was used to minimize dilution of the sample ( $3 \mathrm{~L})$ due to addition of acid. To avoid casein precipitation, the acid was slowly added while the bulk milk was stirred by recirculation at high flow rate using a peristaltic pump. A total of 9 samples were collected at regular $\mathrm{pH}$ intervals $(\sim 0.25 \mathrm{pH}$ units $)$. During sample collection, a $30-\mathrm{mL}$ permeate sample was removed and the same amount of skim milk was added back to the bulk milk to avoid protein concentration. Additional proteins and mineral were added each time $30 \mathrm{~mL}$ of skim milk was added to the bulk milk. However, the total amount was relatively low compared with the total bulk milk (3 L).

\section{Free Calcium Determination}

Free calcium in permeate and milk samples was measured immediately after sample collection using an ionic calcium electrode (Denver Instruments, Denver, CO) calibrated using $\mathrm{CaCl}_{2}$ in distilled water and ionic strength adjuster as recommended by the manufacturer.

\section{Rheological Determinations}

Ultrafiltration permeates and unfiltered skim milk were combined with pectin to study rheological properties. A 1.2\% (wt/vol) solution of LM pectin (LM 35, DE = $30 \%$, TIC Gums Inc., Belcamp, MD) was prepared using distilled water and $0.2 \%$ (wt/vol) sodium azide (Fisher Biotech, Fair Lawn, NJ). For rheological determinations, $20 \mathrm{~mL}$ of milk permeate (or skim milk) and 20 $\mathrm{mL}$ of pectin solution were separately heated to $60^{\circ} \mathrm{C}$ to ensure proper pectin solubilization and immediately mixed. A $12.5-\mathrm{mL}$ aliquot of the pectin-permeate solution was transferred to a peltier concentric cylinder system (rotor radius $=14 \mathrm{~mm}$, rotor height $=42 \mathrm{~mm}$, cup radius $=15 \mathrm{~mm}$ ) in a controlled stress rheometer (model AR-2000, TA Instruments, New Castle, DE). Immediately after transfer, the system was cooled to $10^{\circ} \mathrm{C}$ and after $10 \mathrm{~min}$ of temperature stabilization, the sample was subjected to a dynamic oscillation frequency sweep $(0.01$ to $10 \mathrm{~Hz} ; 0.1 \%$ strain, within the linear region) and storage $\left(\mathrm{G}^{\prime}\right)$ and loss $\left(\mathrm{G}^{\prime \prime}\right)$ moduli were calculated. Experiments were done in duplicate and combined into a single data set. Storage modulus was correlated to free calcium concentration in the same sample, using the Pearson product-moment correlation coefficient (Steel et al., 1997).

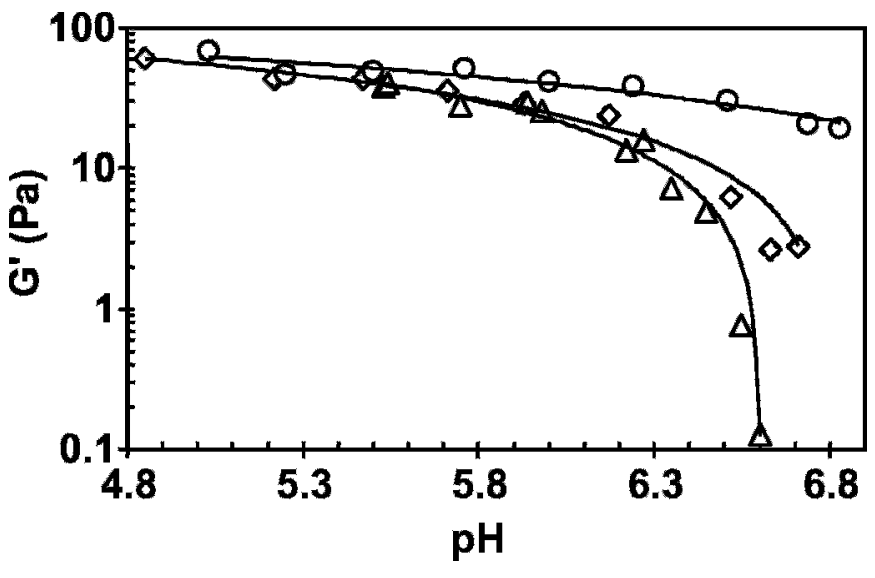

Figure 1. Effect of $\mathrm{pH}$ during $3-\mathrm{kDa}$ molecular weight cut-off ultrafiltration on storage modulus $\left(\mathrm{G}^{\prime}\right)$ for low methoxyl (LM)-pectin $\left(0.6 \% \mathrm{wt} / \mathrm{vol}\right.$ final concentration) mixed with $(\Delta) 40^{\circ} \mathrm{C}$ skim milk permeates, $(\diamond) 7^{\circ} \mathrm{C}$ skim milk permeates, and $(\bigcirc)$ unfiltered skim milk.

\section{Acidified Milk-Pectin Experiment}

A LM-pectin-distilled water (1.2\% wt/vol) solution was added to skim milk at $25^{\circ} \mathrm{C}$ to a final $0.6 \%$ pectin in milk concentration. Immediately after mixing, glucono- $\delta$-lactone (GDL; Sigma Aldrich, St. Louis, MO) in distilled water $(25 \% \mathrm{wt} / \mathrm{vol})$ was added to a final $2.5 \%$ (wt/vol) GDL in milk concentration. Previous GDL dilution was done to avoid local precipitation due to localized high concentration of the weak acid in a small nonstirred sample. The initial addition of the weak acid promoted a drop in $\mathrm{pH}$ to $\sim 6.1$. Immediately after mixing, the final solution was subjected to a time sweep oscillatory testing $\left(25^{\circ} \mathrm{C} ; 0.5 \mathrm{~Hz} ; 0.1 \%\right.$ strain) for $5 \mathrm{~h}$ using the above-mentioned setup. Storage modulus and $\mathrm{pH}$ were recorded every minute during testing.

\section{RESULTS AND DISCUSSION}

The drop in $\mathrm{pH}$ of skim milk during ultrafiltration gradually promoted permeates to exhibit gel-like behavior $\left(\mathrm{G}^{\prime}>1\right)$ when combined with a LM-pectin solution (Figure 1). Because of the low MWCO of the filter (3 $\mathrm{kDa}$ ), only lactose, minerals, and low molecular weight peptides were able to permeate to the ultrafiltered samples. From these 3 components, only the mineral fraction in the milk serum would change as a response to $\mathrm{pH}$ drop during acidification, due to solubilization of micellar $\mathrm{Ca}^{+2}, \mathrm{Mg}^{+2}$, phosphate, and citrate ions into the serum phase (Le Graet and Gaucheron, 1999). The 2 cations promote the ionic polymerization of LM-pectin. However, calcium has a stronger effect promoting gel formation during acidification because it strongly binds to LM-pectin (Malovikova et al., 1994), and because micellar $\mathrm{Ca}^{+2}$ concentration is $\sim 11$ times higher than 


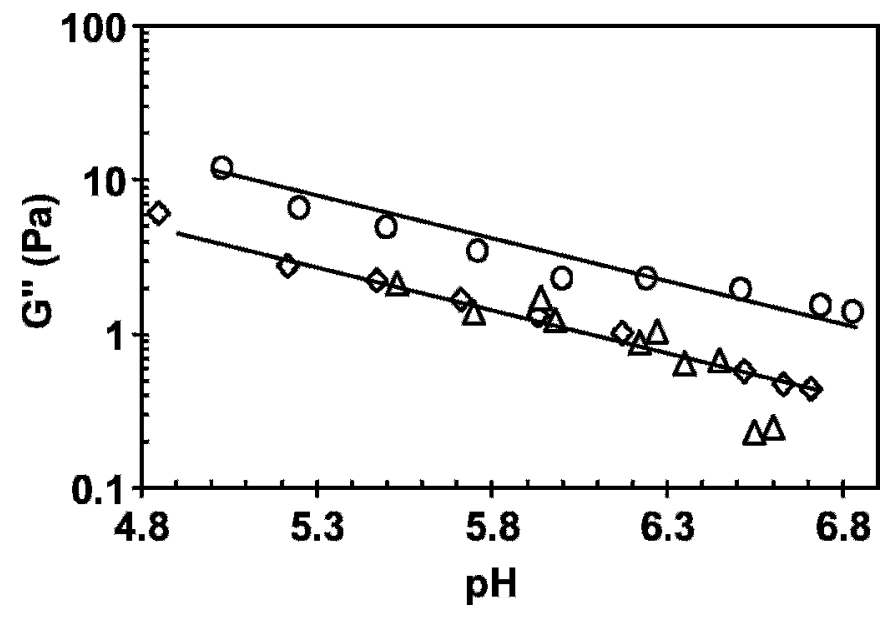

Figure 2. Effect of $\mathrm{pH}$ during $3-\mathrm{kDa}$ molecular weight cut-off ultrafiltration on loss modulus $\left(\mathrm{G}^{\prime \prime}\right)$ for low methoxyl (LM)-pectin $\left(0.6 \% \mathrm{wt} / \mathrm{vol}\right.$ final concentration) mixed with $(\Delta) 40^{\circ} \mathrm{C}$ skim milk permeates, $(\diamond) 7^{\circ} \mathrm{C}$ skim milk permeates, and $(\bigcirc)$ unfiltered skim milk.

$\mathrm{Mg}^{+2}$ (Gaucheron, 2005). The onset of the gel-like behavior occurred at a higher $\mathrm{pH}$ when permeates were obtained from milk filtered at $7^{\circ} \mathrm{C}$ compared with $40^{\circ} \mathrm{C}$ in agreement with data reported by Pouliot et al. (1989) where serum free calcium concentration was inversely related to temperature in the 4 to $60^{\circ} \mathrm{C}$ range. As the $\mathrm{pH}$ during ultrafiltration approached 5 and regardless of temperature, the storage modulus for permeate-pectin mixes showed $G^{\prime}$ values within the same range as skim milk-pectin mixes (Figure 1), indicating that before the $\mathrm{pH}$ reaches the isoelectric point for the caseins ( 4.6), gel formation depends mainly on the calciumpectin interaction, with casein micelles only reducing free water available for gelation. In the case of skim milk samples containing LM-pectin, sample flocculation due to casein coalescence occurred at $\mathrm{pH} 5$. In this way, observed $G^{\prime}$ slightly under represent real $G^{\prime}$ values due to structure modification prior to rheological measurements.

The loss modulus $\left(\mathrm{G}^{\prime \prime}\right)$ followed a log-linear pattern in response to a drop in $\mathrm{pH}$ and was unaffected by ultrafiltration temperature (Figure 2). Over the whole $\mathrm{pH}$ range for the experiments, a constant $\sim 0.5$ log difference between skim milk-pectin and permeate-pectin was observed.

The concentration of ionic calcium in milk and permeate samples depended on the $\mathrm{pH}$ value, consistent with data previously reported by Le Graet and Gaucheron (1999), where lower $\mathrm{pH}$ values resulted in higher calcium concentration (Figure 3 ). The storage modulus $\left(G^{\prime}\right)$ for permeate-pectin mix increased with increasing calcium concentration and showed high correlation $(\mathrm{r}=$ 0.953 ) independently of ultrafiltration temperature.

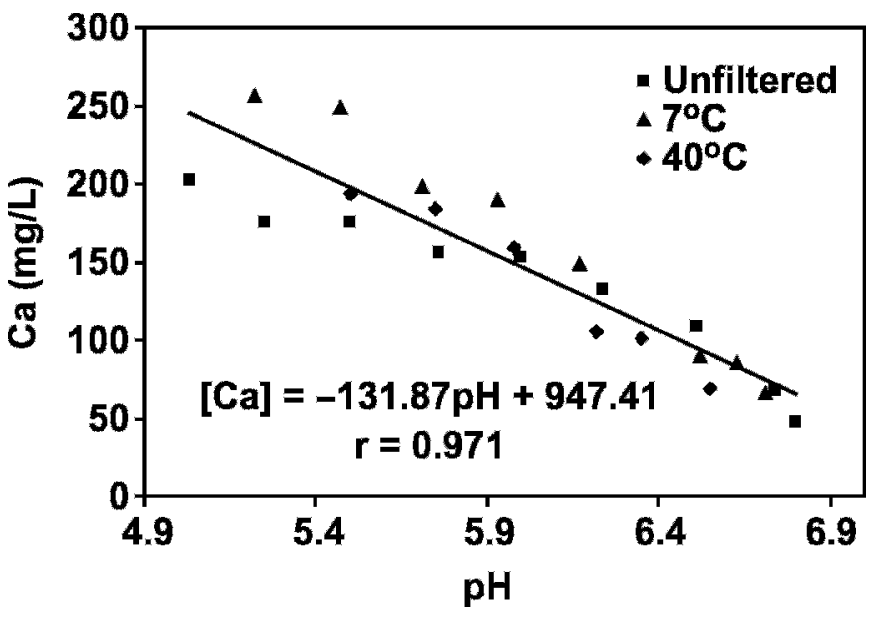

Figure 3. Free calcium concentration vs. $\mathrm{pH}$ of unfiltered skim milk, and skim milk permeate filtrated at 40 and $7^{\circ} \mathrm{C}$.

The storage modulus $\left(\mathrm{G}^{\prime}\right)$ for skim milk-pectin mixes followed a similar pattern $(r=0.983)$; however, for tested calcium concentrations $\mathrm{G}^{\prime}$ values were, in all cases, approximately $20 \mathrm{~Pa}$ greater than those for permeate-pectin mixes (Figure 4). These results show that above $\mathrm{pH} 5$ and before electrosorption of pectin into casein micelles occur within 5.0 to $3.5 \mathrm{pH}$ range (Tuinier et al., 2002), ionic calcium migrating from the casein micelle into the serum plays a major role promoting pectin aggregation due to intermolecular crosslinking by ionic calcium.

Rheological determinations were also done in skim milk containing LM-pectin. In this case the $\mathrm{pH}$ modification was done in situ (within the rheometer), using a weak acid (GDL) to avoid flocculation before measurements. A sharp increase in storage modulus was ob-

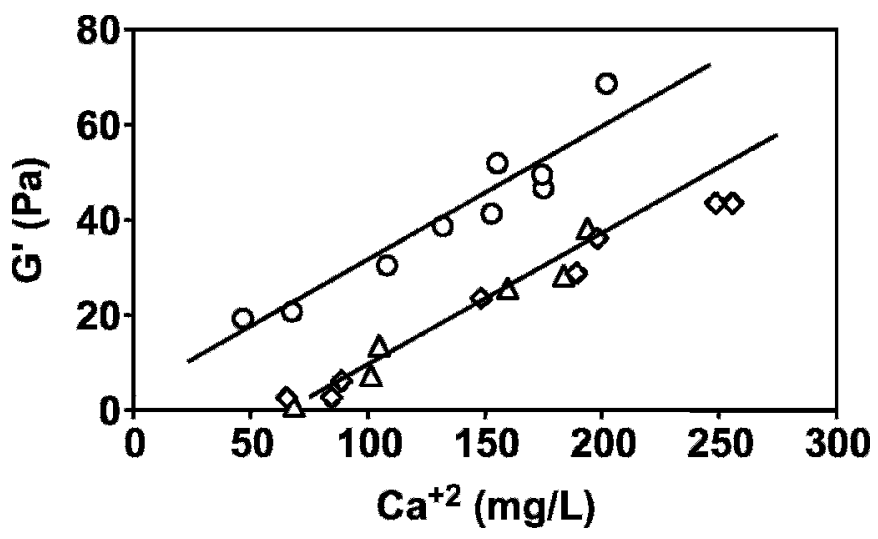

Figure 4. Storage modulus $\left(G^{\prime}\right)$ for low methoxyl (LM)-pectin $(0.6 \%$ wt/vol final concentration) mixed with $(\Delta) 40^{\circ} \mathrm{C}$ skim milk permeate, $(\diamond) 7^{\circ} \mathrm{C}$ skim milk permeate, and $(\bigcirc)$ unfiltered skim milk as a function of measured free calcium. 


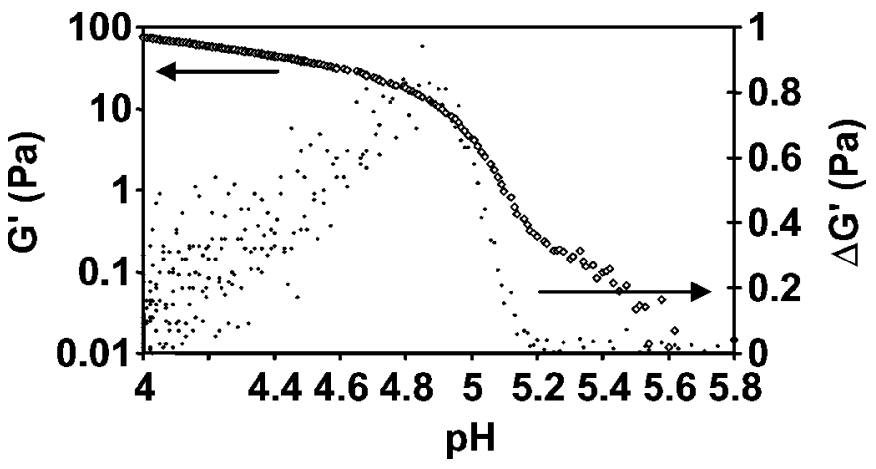

Figure 5. Storage modulus $\left(\mathrm{G}^{\prime}\right)$ and storage modulus increment $\left(\Delta \mathrm{G}^{\prime}\right)$ vs. $\mathrm{pH}$ for a skim milk-pectin $(0.5 \% \mathrm{wt} / \mathrm{vol})$ acidified by glucono$\delta$-lactone.

served as the $\mathrm{pH}$ approached 5.2 and a maximum $\mathrm{G}^{\prime}$ increment $\left(\Delta \mathrm{G}^{\prime}\right)$ at $\mathrm{pH} \sim 5.0$ to 4.9 (Figure 5). From $\mathrm{pH}$ $5.0-4.9$ to $\mathrm{pH} 4, \mathrm{G}^{\prime}$ continued to increase but with gradually decreasing increments. These observations were consistent with previous reports showing that at casein micelle concentration comparable with that of milk, micellar ionic calcium depletion is complete as $\mathrm{pH}$ approaches 4.9 to 5.0 (Law, 1996; Le Graet and Gaucheron, 1999).

Figure 6 shows the proposed model for LM pectincasein micelle interaction as $\mathrm{pH}$ drops during acidification. At $\mathrm{pH}$ of milk (Figure 6A), $\kappa$-casein acts as an electrostatic and physical barrier toward aggregation of adjacent casein micelles (de Kruif, 1999) and LMpectin remains dispersed in the serum phase. As $\mathrm{pH}$ decreases (Figure 6B), calcium ions migrate from the casein micelle to the serum phase and promote crosslinking of LM-pectin chains. Near pH 5.0 (Figure 6C), micelles are depleted of ionic calcium, the $\kappa$-casein brush collapses, and maximized calcium-induced LMpectin aggregation occurs. A further drop in $\mathrm{pH}$ to $\sim 4.6$ (Figure 6D) promotes the isoelectric aggregation of casein micelles and contributes to the formation of caseinpectin complexes. Our results indicate that pectin-pectin interaction derived from ionic calcium solubilization from the casein micelle into the serum dominates changes in rheological properties of LM-pectin milk mixtures as $\mathrm{pH}$ is dropped to 5.0 to 4.9 . Below $\mathrm{pH} 5.0$ to 4.9 , electrosorption of pectin ionic complexes into the surface casein micelles (as reported by Tromp et al., 2004) and casein micelle coalescence would drive further changes in the rheological properties of LM-pectin in milk.

\section{CONCLUSIONS}

Ionic calcium migration from casein micelles into the milk serum during acidification promotes the interac-
A)

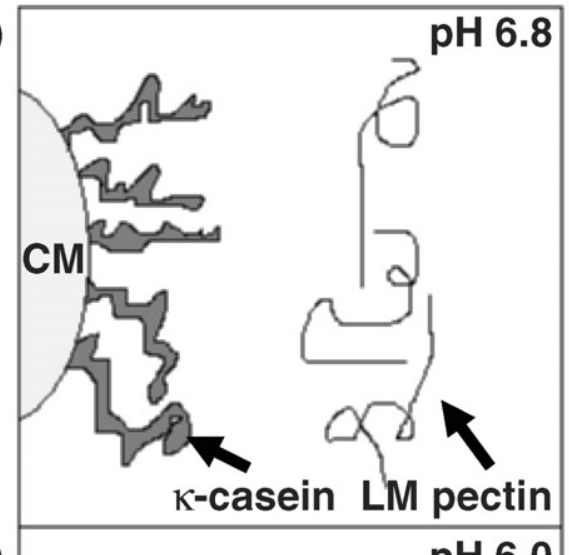

B)

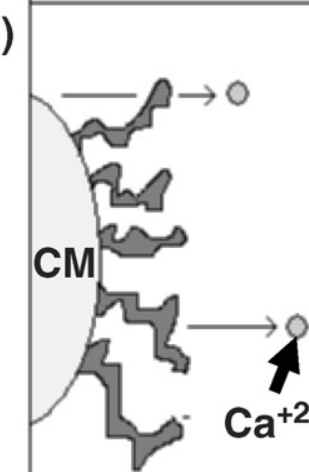

pH 6.0

C)
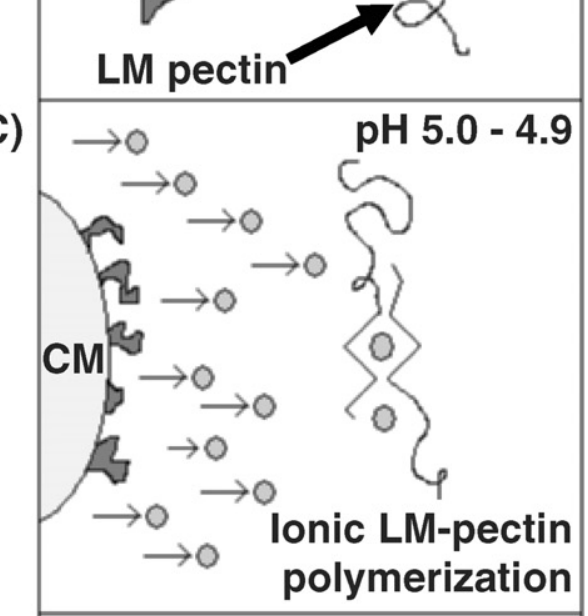

D)

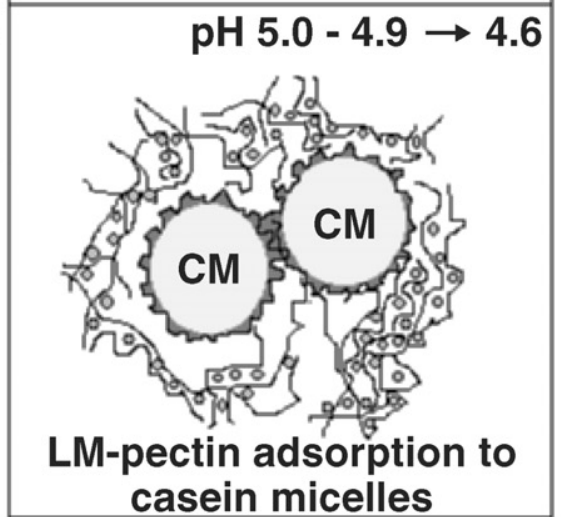

Figure 6. Proposed model for low methoxyl (LM)-pectin-casein micelle $(\mathrm{CM})$ interaction during milk acidification. 
tion among LM pectin strands before the isoelectric aggregation of the casein micelles occurs. Results indicate that as the $\mathrm{pH}$ drops to 5.0 to 4.9 , rheological properties of casein micelle-LM pectin mixes are mainly dependent on serum ionic calcium concentration. The LM-pectin-casein interaction in milk-based products is a 2-step process: 1) solubilized micellar calcium-dependent pectin-pectin interaction as $\mathrm{pH}$ approaches 5.0 to 4.9 , and 2) pectin-casein interaction in the 5.0-4.9 to $4.0 \mathrm{pH}$ range.

\section{ACKNOWLEDGMENT}

This research was funded by the University of Tennessee, College of Agriculture through the hatch project No. TEN00332.

\section{REFERENCES}

de Kruif, C. G. 1999. Casein micelle interactions. Int. Dairy J. 9:183-188.

Everett, D. W., and R. E. McLeod. 2005. Interactions of polysaccharide stabilisers with casein aggregates in stirred skim-milk yoghurt. Int. Dairy J. 15:1175-1183.

Fox, P. F., and P. McSweeney. 1998. Dairy Chemistry and Biochemistry. Springer, New York, NY.
Gaucheron, F. 2005. The minerals of milk. Reprod. Nutr. Dev. 45:473-483.

Holt, C., and R. Jenness. 1984. Interrelationships of constituents and partition of salts in milk samples from eight species. Comp. Biochem. Physiol., Part A Mol. Integr. Physiol. 77A:275-282.

Horne, D. S. 2003. Caseins, micellar structures. Pages 1902-1909 in H. Roginski, J. W. Fuquay, and P. F. Fox. Encyclopedia of Dairy Sciences, Vol. 3. Academic Press, New York, NY.

Law, A. J. R. 1996. Effects of heat treatment and acidification on the dissociation of bovine casein micelles. J. Dairy Res. 63:35-48.

Le Graet, Y., and F. Gaucheron. 1999. pH-induced solubilization of minerals from casein micelles: Influence of casein concentration and ionic strength. J. Dairy Res. 66:215-224.

Malovikova, A., M. Rinaudo, and M. Milas. 1994. Comparative interactions of magnesium and calcium counterions with polygalacturonic acid. Biopolymers 34:1059-1064.

Maroziene, A., and C. G. de Kruif. 2000. Interaction of pectin and casein micelles. Food Hydrocoll. 14:391-394.

Morris, V. J. 1998. Gelation of polysaccharides. Pages 143-226 in Functional Properties of Food Macromolecules. S. E. Hill, D. A. Ledward, and J. R. Mitchell, ed. Aspen Publication, New York, NY.

Pouliot, Y., M. Boulet, and P. Paquin. 1989. Observations on the heat-induced salt balance changes in milk. I. Effect of heating time between 4 and $90^{\circ}$. J. Dairy Res. 56:185-192.

Steel, R. G. D., J. H. Torrie, and D. A. Dickey. 1997. Principles and procedures of statistics: A biometrical approach. McGraw-Hill, New York, NY.

Tromp, R. H., C. G. de Kruif, M. van Eijk, and C. Rolin. 2004. On the mechanism of stabilisation of acidified milk drinks by pectin. Food Hydrocoll. 18:565-572.

Tuinier, R., C. Rolin, and C. G. de Kruif. 2002. Electrosorption of pectin onto casein micelles. Biomacromolecules 3:632-638. 